\title{
Stress at work: The case of municipal police officers
}

\author{
Ilona Cieślak ${ }^{\mathrm{a}}$, Aleksandra Kielan ${ }^{\mathrm{b}}$, Dominik Olejniczak ${ }^{\mathrm{b}}$, Mariusz Panczyk ${ }^{\mathrm{a}, *}$, Mariusz Jaworski ${ }^{\mathrm{a}}$, \\ Robert Gałązkowskic,d, Jakub R. Pękala ${ }^{\mathrm{e}}$, Lucyna Iwanow ${ }^{\mathrm{a}}$, Aleksander Zarzeka ${ }^{\mathrm{a}}$, \\ Joanna Gotlib ${ }^{\mathrm{a}}$ and Marcin Mikos ${ }^{\mathrm{f}}$ \\ ${ }^{a}$ Division of Education and Research in Health Science, Faculty of Health Science, Medical University \\ of Warsaw, Warsaw, Poland \\ ${ }^{\mathrm{b}}$ Division of Public Health, Faculty of Health Science, Medical University of Warsaw, Warsaw, Poland \\ ${ }^{\mathrm{c}}$ Department of Emergency Medical Services, Faculty of Health Science, Medical University \\ of Warsaw, Warsaw, Poland \\ ${ }^{\mathrm{d}}$ Polish Medical Air Rescue, Warsaw, Poland \\ ${ }^{\mathrm{e}}$ Department of Anatomy, Jagiellonian University Medical College, Kraków, Poland \\ ${ }^{\mathrm{f}}$ Andrzej Frycz Modrzewski Krakow University, Kraków, Poland
}

\begin{abstract}
.
INTRODUCTION AND OBJECTIVE: Occupational stress-related factors among working municipal police officers in Poland have not been examined in the literature. The purpose of the paper was to evaluate the impact of selected work-related factors on occupational stress in active municipal police officers in Warsaw by using configural frequency analysis (CFA).

MATERIALS AND METHODS: A cross-sectional study was conducted among 578 participants, which accounted for $55.1 \%$ of all municipal police officers in Warsaw. The majority of study participants were men (72\%) (mean age 43 years old). Two groups of workplace-related stress factors were analysed in the study: physical conditions and organisational working conditions causing stress. The study was carried out using the PAPI method (Paper-and-Pencil Interviewing), based on a proprietary questionnaire developed for the study. CFA searches for templates and patterns in contingency tables.

RESULTS: Municipal police officers who claimed that stress did not affect health, took advantage of psychologi$\mathrm{cal} / \mathrm{psychiatric}$ advice less often than those who thought so $(1.7 \%$ vs $10.1 \% ; \chi 2=20.152, \mathrm{df}=2, P=0.000)$. Those who declared that they often experienced stress at work were also more prone to claiming that one or two factors affected their level of stress: physical abuse, contact with infectious materials, working at uncomfortable temperatures or working in a noisy environment. In the opinion of the study population, there were some factors which contributed to the occurrence of stress at work, and these factors included: working in a hurry, lack of necessary resources, devices and materials at work, the need to be available at all times and the unpredictability of the work. The municipal police officers from the study population combined two or three methods to cope with stress, such as watching TV, surfing the Internet and talking with their families. CONCLUSION: Due to the specificity of a municipal police officer's occupation, special attention should be paid to the occupational stress risk factors characteristic for this group of professionals, and measures should be taken to reduce the number of stressors. It is important to organise training events devoted to effective methods of coping with stress. There is need to carry out more in-depth studies of occupational stress among municipal police officers.
\end{abstract}

Keywords: Safety, health at work, occupational medicine, uniformed services

*Address for correspondence: Mariusz Panczyk, Division of Education and Research in Health Science, Faculty of Health Science, Medical University of Warsaw, 81 Zwirki i Wigury St.,
02-091 Warsaw, Poland. Tel.: +48 22 5720490; E-mail: mariusz. panczyk@wum.edu.pl. 


\section{Introduction}

Stress is a psychosocial phenomenon experienced by humans in different situations. According to Lazarus and Folkman [1], stress is approached as a specific relationship between a human and their environment. Situations subjectively perceived as threatening may occur not only in our everyday lives but also, very often, at work [2]. Researchers point out that being subjected to social evaluation by other people and the high requirements of our environment are among important factors contributing to occupational stress [3].

It is estimated that $85 \%$ of employees in Poland experience stress at work, while the percentage in Warsaw amounts to 94\% [4]. Uniformed services are among occupational groups particularly exposed to occupational stress [5-8]. Nevertheless, publications pay less attention to occupational stress among active municipal police officers [9-11].

The structure of the municipal police agency consists of three main divisions: Prevention, Operation and Logistics. The employees of the Prevention Division form the most numerous group. Local branches in specific districts are responsible for public order within the division. There are seven local branches of the Prevention Division. The main tasks of the Municipal Police of the capital city of Warsaw include:

- protection of peace and order in public places

- cooperation with relevant entities to safeguard the life and health of citizens, help to repair technical failures, and provide support during natural disasters

- protection of a crime scene, disaster area or similar, which is at risk of re-occurrence, unauthorised access or damaging of evidence; identification of witnesses

- cooperation with other services to keep order during public gatherings and events

- transportation of intoxicated individuals to drunk tanks or their places of residence, if their behaviour is causing disturbance in public places or if they find themselves in circumstances that can be a hazard for their life or health, or the life or health of other people

- informing the local community about the status and types of current hazards; organising and participating in activities aimed at crime prevention, in cooperation with state and local authorities, and social organisations
- transfer of documents, valuables or cash for the municipality [12].

Each of the aforementioned duties can constitute a hazard for the life and health of municipal police officers. Their occupation is classified as a high-risk job.

Municipal police officers share a variety of stressinducing factors with active police officers [13]. Such factors include shift working, long working hours, frequent conflicts and unpredictability at work [14, 15]. The work of a municipal police officer is intrinsically related to occupational risk and danger [16-19]. Spielberger et al. [20] classified stressors related to a policeman's job in three main categories: administrative and occupational pressure, physical and mental hazards, and lack of support within and outside the organisation. The most common organisational stressors include work overload, which results from an insufficient workforce, low salaries that do not correspond to the responsibilities involved, and too much monotonous administrative work [21]. Considering the lack of relevant studies devoted to the intensification of stress at work among active municipal police officers, the authors designed their own study.

\section{Purpose}

The purpose of the paper was to evaluate the impact of selected work-related factors on stress at work experienced by active municipal police officers in Warsaw by using configural frequency analysis (CFA).

\section{Materials and methods}

A cross-sectional study was conducted among 578 people, i.e. $55.1 \%$ of all working municipal police officers in Warsaw, employed in the Prevention Division (number of employees in 2016 - 1,049). For such a study population size, the measurement error was 2.78\% (assumption: 0.95 confidence range and 0.50 proportion). The study was carried out between April and September 2015 among employees of the local branches of the Prevention Division of the municipal police agency. The Prevention Division is the largest and most numerous structure in the Municipal Police. The main task of the Division is to protect public order and to ensure peace and quiet in the area of the city of Warsaw. To that end, the majority of municipal police officers are involved in the implementation of the Prevention Division tasks and, hence, consti- 
Table 1

Characteristics of the study population

\begin{tabular}{|c|c|}
\hline \multicolumn{2}{|l|}{ Age $(M \pm \mathrm{SD})$} \\
\hline M & 43.0 \\
\hline $\mathrm{SD}$ & 8.49 \\
\hline \multicolumn{2}{|l|}{ Gender (N, \%) } \\
\hline Female & $159(27.5)$ \\
\hline Male & $419(72.5)$ \\
\hline \multicolumn{2}{|l|}{ Education (N, \%) } \\
\hline Primary & $21(3.6)$ \\
\hline Secondary & $317(54.8)$ \\
\hline Higher & $240(41.5)$ \\
\hline \multicolumn{2}{|l|}{ Seniority $(N, \%)$} \\
\hline$\leq 3$ years & $11(1.9)$ \\
\hline From 4 to 7 years & $75(13.0)$ \\
\hline From 8 to 11 years & $153(26.5)$ \\
\hline From 12 to 15 years & $75(13.0)$ \\
\hline$>15$ years & $264(45.7)$ \\
\hline \multicolumn{2}{|l|}{ Marital status (N, \%) } \\
\hline Single & $177(30.6)$ \\
\hline Married & $401(69.4)$ \\
\hline \multicolumn{2}{|l|}{ Police rank (N, \%) } \\
\hline Trainee & $7(1.2)$ \\
\hline Junior Municipal Police Officer & $52(9.0)$ \\
\hline Municipal Police Officer & $94(16.3)$ \\
\hline Senior Police Officer & $91(15.7)$ \\
\hline Junior Specialist & $31(5.4)$ \\
\hline Specialist & $13(2.2)$ \\
\hline Senior Specialist & $8(1.4)$ \\
\hline Junior Inspector & $67(11.6)$ \\
\hline Inspector & $72(12.5)$ \\
\hline Senior Inspector & $118(20.4)$ \\
\hline Deputy Head & $1(.2)$ \\
\hline Head & $21(3.6)$ \\
\hline Chief Officer & $1(.2)$ \\
\hline Missing data & $2(.3)$ \\
\hline \multicolumn{2}{|l|}{ Having children (N, \%) } \\
\hline Yes & $451(78.0)$ \\
\hline No & $127(22.0)$ \\
\hline
\end{tabular}

tuted the majority of our study population. The age, job seniority and gender of the study population were similar to the total population of the municipal police agency. The characteristics of the study population are presented in Table 1.

Upon obtaining a permit from the Commanderin-Chief of the police agency to conduct the study, every Prevention Division officer, who was present during the morning briefing on the given day, filled the questionnaire in less than 15 minutes. The authors organised the study and instructed the participants to fill the questionnaires. Participation in the study was voluntary and anonymous. All municipal police officers on duty on the day of the survey were invited to participate in the study. The study was performed using the PAPI method (Paper-and-Pencil Interviewing) and a proprietary questionnaire developed for the study.
The proprietary questionnaire was developed based on a literature review. Papers which met the following criteria were included: 1) they were original papers, 2) they applied to uniformed services, such as police and municipal police, 3 ) they were written in English, and 4) they were published before 2014. The literature review was performed using the PubMed database, with a competent judge method. The group of competent judges included: two public health specialists, a psychologist and a statistician. Papers were searched for using the following combinations of keywords: occupational stress, stress at work. Based on the data, the authors developed a list of physical and organisational factors, and factors related to the position held and the degree of work overload. The team of competent judges divided the stress factors identified based on the literature review into two groups. The first group covered physical conditions that cause stress, while the second applied to organisational working conditions causing stress. The physical conditions that cause stress included: 1) working in a noisy environment, 2) working at too high/low temperature, 3) contact with infectious materials, 4) physical abuse, threatening, bullying, 5) physical factors do not contribute to my stress. Organisational working conditions causing stress included: 1) unpredictability at work, 2) need to be available at all times, 3) lack of necessary resources, devices and materials, 4) need to work in a hurry, 5) organisational factors do not contribute to my stress.

Additionally, a list of questions was added to the questionnaire related to methods of coping with stress used by the study participants, and their knowledge of meetings devoted to managing occupational stress held at their workplace. The questions were formulated as follows: "What stress reducing methods do you use most often?" and "Are meetings devoted to coping with stress organised in your workplace?".

The questions targeted the respondents' opinions about the impact of stressors at work on their health condition, and their views on the frequency of seeking psychological and psychiatric advice related to workplace stress. Sample questions from the questionnaire included: "Do you consider your job more stressful than jobs not related to uniformed services?", "Do you experience stress in relation to your job?", "Do you consider stress necessary in the workplace?", "Do you think that occupational stress affects your health?", "Have you ever turned to a psychologist/psychiatrist for advice?" and "Do your superiors provide the possibility to obtain a psychologist's/psychiatrist's advice?". 
Considering the non-metric nature of the analysed variables, a non-parametric approach was used for the analysis of the obtained data. The data were presented by means of contingency tables and evaluation of the relationships between variables using $\chi 2$ Pearson test and Crammér's V effect size. Configure frequency analysis (CFA) was applied to assess accurately the correlation between variables [22, 23]. This analysis is intended to look for patterns in contingency tables. It examines whether certain patterns occur more often (type T) or less often (antitype A) in the collected data than chance might allow. In this study, the search for patterns was conducted in order to find the most frequent configurations of answers related to the following groups of variables: (a) the impact of selected physical factors on stress, (b) the impact of organisational working conditions causing stress, (c) work overload, and (d) the methods of coping with stress. For all analyses, a $P$-value below 0.05 was taken as significant. In CFA, the Bonferroni correction was used to compute $P$-values. Statistical analysis was carried out using Statistica 13.3. (TIBCO Software Inc.).

Pursuant to the policy of the Bioethics Committee of the Medical University of Warsaw, surveys, retrospective studies, and non-invasive scientific studies do not require a permit by the Committee [24].

\section{Results}

A relationship was observed between views on the impact of occupational stressors and the frequency of consulting with a psychologist/psychiatrist (Table 2). The municipal police officers who claimed that workrelated stressors affected their health were more likely to consult with a psychologist/psychiatrist than those who did not think so $(10.1 \%$ vs $1.7 \% ; \chi 2=20.152$, $\mathrm{df}=2, P=0.000 ; V=0.19$ ).
Table 2

Respondents' answers to the questions: "Have you ever taken a psychologist's/psychiatrist's advice?" and "Do you think that stress at work affect your health?'

\begin{tabular}{|c|c|c|}
\hline \multirow[t]{2}{*}{$\begin{array}{l}\text { Taking psychologist's/ } \\
\text { psychiatrist's advice }\end{array}$} & \multicolumn{2}{|c|}{$\begin{array}{c}\text { Does stress at } \\
\text { work affect health? }\end{array}$} \\
\hline & Yes & No \\
\hline Yes, regularly/ Yes, a few times & $41(10.1)$ & $3(1.7)$ \\
\hline Yes, once & $39(9.6)$ & $6(3.5)$ \\
\hline No & $325(80.3)$ & $164(94.8)$ \\
\hline
\end{tabular}

The CFA results revealed that people who claimed that a municipal police officer's work was more stressful than other jobs, that were non-uniformed services, and who experienced stress in their work every day or often, were of the opinion that one or two physical factors affected the level of stress they experienced at work (Table 3). Physical abuse combined with such factors as contact with infectious materials, working at too high/low temperatures and working in a noisy environment were accounted for most often.

Moreover, the CFA results showed that people who claimed that a municipal police officer's work is more stressful than other jobs and who experienced stress in their work every day or often, were of the opinion that one or two factors related to the organisation of their work affected the level of stress they experienced at work more often than one would expect (Table 4). The most commonly listed factors in this group included the need to work in a hurry, combined with such factors as the lack of necessary resources, devices and materials, the need to be available at all times and the unpredictability of the work.

The results of the CFA indicated that people who claimed that a municipal police officer's work was more stressful than other jobs and that they experienced stress at work every day or often, were more prone to thinking that one or two factors related to work overload affected the level of stress they expe-

Table 3

Opinion template concerning an impact of selected physical factors on stress in the studied group whose members claim that a job of a municipal police officer is more stressful than other jobs and that they experience stress in their work every day or often (frequency of response in brackets)

\begin{tabular}{|c|c|c|c|c|c|c|}
\hline \multicolumn{5}{|c|}{ Physical conditions that cause stress } & \multirow[b]{2}{*}{$\chi^{2}$} & \multirow[b]{2}{*}{$P$-value } \\
\hline $\begin{array}{l}\text { Working in } \\
\text { noisy } \\
\text { environment }\end{array}$ & $\begin{array}{l}\text { Working at } \\
\text { too high/low } \\
\text { temperature }\end{array}$ & $\begin{array}{c}\text { Contact with } \\
\text { infectious } \\
\text { materials }\end{array}$ & $\begin{array}{c}\text { Physical abuse, } \\
\text { threatening, } \\
\text { bullying }\end{array}$ & $\begin{array}{c}\text { Physical factors } \\
\text { do not contribute } \\
\text { to my stress }\end{array}$ & & \\
\hline No $(0.76)$ & No (0.79) & Yes $(0.26)$ & Yes $(0.40)$ & No $(0.75)$ & 4.34 & 0.001 \\
\hline No $(0.76)$ & Yes $(0.21)$ & No (0.74) & Yes $(0.40)$ & No $(0.75)$ & 5.21 & 0.001 \\
\hline Yes $(0.24)$ & No (0.79) & No $(0.74)$ & Yes $(0.40)$ & No $(0.75)$ & 4.05 & 0.000 \\
\hline Yes $(0.76)$ & Yes $(0.21)$ & No $(0.74)$ & No $(0.60)$ & No $(0.75)$ & 8.27 & 0.000 \\
\hline No $(0.24)$ & Yes $(0.21)$ & Yes $(0.26)$ & No $(0.60)$ & No $(0.75)$ & 5.50 & 0.000 \\
\hline Yes $(0.76)$ & No $(0.79)$ & Yes $(0.26)$ & No $(0.60)$ & No $(0.75)$ & 5.31 & 0.000 \\
\hline
\end{tabular}


Table 4

Opinion template concerning the impact of organisational working conditions causing stress in the studied group whose members claim that a job of a municipal police officer is more stressful than other jobs and that they experience stress in their work every day or often (frequency of response in brackets)

\begin{tabular}{|c|c|c|c|c|c|c|}
\hline \multicolumn{5}{|c|}{ Organisational working conditions causing stress } & \multirow[b]{2}{*}{$\chi^{2}$} & \multirow[b]{2}{*}{$P$-value } \\
\hline $\begin{array}{l}\text { Unpredictability } \\
\text { of work }\end{array}$ & $\begin{array}{l}\text { Need to be } \\
\text { available all } \\
\text { the time }\end{array}$ & $\begin{array}{l}\text { Lack of necessary } \\
\text { resources, devices } \\
\text { and materials }\end{array}$ & $\begin{array}{l}\text { Need to work } \\
\text { in a hurry }\end{array}$ & $\begin{array}{l}\text { Organisational factors } \\
\text { do not contribute } \\
\text { to my stress }\end{array}$ & & \\
\hline No $(0.57)$ & No $(0.86)$ & Yes $(0.69)$ & Yes $(0.70)$ & No $(0.78)$ & 5.80 & 0.000 \\
\hline No $(0.57)$ & Yes $(0.41)$ & No $(0.31)$ & Yes $(0.70)$ & No $(0.78)$ & 5.30 & 0.000 \\
\hline Yes $(0.43)$ & No $(0.86)$ & No $(0.31)$ & Yes $(0.70)$ & No $(0.78)$ & 5.67 & 0.000 \\
\hline Yes $(0.43)$ & No $(0.86)$ & Yes (0.69) & No $(0.30)$ & No $(0.78)$ & 6.50 & 0.000 \\
\hline Yes $(0.43)$ & Yes $(0.14)$ & No $(0.31)$ & No $(0.30)$ & No $(0.78)$ & 7.07 & 0.000 \\
\hline
\end{tabular}

Table 5

Opinion template concerning being overloaded with work in the studied group whose members claim that a job of a municipal police officer is more stressful than other jobs, not related to uniform services and that they experience stress in their work every day or often (frequency of response in brackets)

\begin{tabular}{|c|c|c|c|c|c|c|c|}
\hline \multicolumn{6}{|c|}{ Factors related to being overloaded with work } & \multirow[b]{2}{*}{$\chi^{2}$} & \multirow[b]{2}{*}{$P$-value } \\
\hline $\begin{array}{l}\text { Need to work } \\
\text { overtime }\end{array}$ & $\begin{array}{c}\text { Working shifts/ } \\
\text { at night }\end{array}$ & $\begin{array}{c}\text { Need for great } \\
\text { physical effort } \\
\text { at work }\end{array}$ & $\begin{array}{c}\text { Responsibility for } \\
\text { life and health } \\
\text { of other people }\end{array}$ & $\begin{array}{c}\text { Dangerous } \\
\text { interventions } \\
\text { and situations }\end{array}$ & $\begin{array}{c}\text { Hazard to } \\
\text { municipal police } \\
\text { officer's life }\end{array}$ & & \\
\hline No $(0.91)$ & No $(0.75)$ & No $(0.95)$ & No $(0.74)$ & Yes $(0.31)$ & Yes $(0.27)$ & 6.53 & 0.000 \\
\hline No $(0.91)$ & Yes $(0.25)$ & No $(0.95)$ & No $(0.74)$ & Yes $(0.31)$ & No $(0.73)$ & 5.72 & 0.000 \\
\hline No $(0.91)$ & No $(0.75)$ & No $(0.95)$ & Yes $(0.26)$ & Yes $(0.31)$ & No $(0.73)$ & 5.01 & 0.000 \\
\hline No $(0.91)$ & No $(0.75)$ & Yes $(0.05)$ & Yes $(0.26)$ & No (0.69) & No $(0.73)$ & 4.41 & 0.000 \\
\hline Yes $(0.09)$ & No $(0.75)$ & No $(0.95)$ & Yes $(0.26)$ & No (0.69) & No $(0.73)$ & 8.22 & 0.000 \\
\hline Yes $(0.09)$ & No $(0.75)$ & Yes $(0.05)$ & No $(0.74)$ & No (0.69) & No $(0.73)$ & 6.98 & 0.000 \\
\hline
\end{tabular}

rienced at work (Table 5). Dangerous interventions and situations in combination with such factors as risks to a municipal police officer's life, responsibility for the health and life of other people and working shifts/at night were listed most often in this group. Another commonly mentioned factor included the responsibility for the life and health of other people.

Based on the results of the CFA it can be concluded that people who claimed that a municipal police officer's work was more stressful than other jobs and that they experienced stress at work every day or often, were more prone to using a combination of two or three different methods of coping with stress (Table 6). The most commonly mentioned combination included watching TV, followed by surfing the Internet and talking with family.

\section{Discussion}

An analysis of different factors related to the specificity of a municipal police officer's work and a representative group of respondents form the strengths of the presented study. Another advantage is that the results provide insight on the factors related specifically to the examined line of work and their relationship with experiencing work-related stress.

The issue of stress at work among municipal police officers is not frequently mentioned in the literature. Papers by non-Polish authors refer to the issue in the context of police officers, fire-fighters and soldiers [6-11] but not municipal police officers. One should pay attention to the fact that a municipal police officer's work encompasses a different scope of responsibilities than other uniformed services. That is why municipal police officers are exposed to occupational stress related to their specific duties and responsibilities.

The results of this research revealed that many factors could become sources of stress for a municipal police officer. These include physical and organisational factors, factors related to work overload and the position held within the organisation. The results correspond to the reports of other researchers and also reveal that the discussed factors are not only typical of police officers [25-27] but of municipal police officers as well.

As regards physical factors, it was observed that a combination of the following two factors 
Table 6

Opinion template concerning the methods of coping with stress in the studied group whose members claim that a job of a municipal police is more stressful than other jobs and that they experience stress in their work every day or often (frequency of response in brackets)

\begin{tabular}{|c|c|c|c|c|c|c|c|c|c|c|}
\hline \multicolumn{9}{|c|}{ Methods of coping with stress } & \multirow[b]{2}{*}{$\chi^{2}$} & \multirow[b]{2}{*}{$P$-value } \\
\hline Sports & Sleeping & $\begin{array}{l}\text { Talking with } \\
\text { family }\end{array}$ & $\begin{array}{l}\text { Talking with } \\
\text { friends }\end{array}$ & $\begin{array}{c}\text { Going out } \\
\text { (theatre, cinema, } \\
\text { opera) }\end{array}$ & $\begin{array}{c}\text { Watching } \\
\text { TV }\end{array}$ & $\begin{array}{c}\text { Reading } \\
\text { books, } \\
\text { magazines }\end{array}$ & $\begin{array}{l}\text { Surfing } \\
\text { the } \\
\text { Internet }\end{array}$ & $\begin{array}{c}\text { I don't use any } \\
\text { stress reduction } \\
\text { method }\end{array}$ & & \\
\hline No $(0.56)$ & No $(0.62)$ & No $(0.82)$ & No $(0.85)$ & No $(0.93)$ & Yes $(0.20)$ & No $(0.81)$ & Yes $(0.19)$ & No $(0.87)$ & 4.50 & 0.000 \\
\hline No $(0.56)$ & No $(0.62)$ & No $(0.82)$ & Yes $(0.15)$ & No $(0.93)$ & Yes $(0.20)$ & No $(0.81)$ & Yes $(0.19)$ & No $(0.87)$ & 4.29 & 0.000 \\
\hline No $(0.56)$ & No $(0.62)$ & Yes $(0.18)$ & No $(0.85)$ & No $(0.93)$ & Yes $(0.20)$ & No $(0.81)$ & Yes $(0.19)$ & No $(0.87)$ & 9.96 & 0.000 \\
\hline No $(0.56)$ & No $(0.62)$ & Yes $(0.18)$ & No $(0.85)$ & Yes (0.07) & No (0.80) & Yes (0.19) & No (0.81) & No $(0.87)$ & 7.21 & 0.000 \\
\hline No $(0.56)$ & Yes $(0.38)$ & No $(0.82)$ & Yes $(0.15)$ & No (0.93) & Yes $(0.20)$ & No $(0.81)$ & No $(0.81)$ & No $(0.87)$ & 6.61 & 0.000 \\
\hline Yes $(0.44)$ & Yes $(0.38)$ & Yes $(0.18)$ & No $(0.85)$ & No $(0.93)$ & No $(0.80)$ & No $(0.81)$ & No $(0.81)$ & No $(0.87)$ & 8.17 & 0.000 \\
\hline
\end{tabular}

was of greatest importance: contact with infectious materials and working at too high/low temperatures. It should be emphasised that some researchers highlight the impact of physical factors on the level of stress experienced at work. Special attention is paid to the issue of violence. Representatives of uniformed services are often exposed to situations in which they can experience different forms of aggression (verbal or physical) [25-27]. According to the presented studies, physical abuse constitutes an important aspect of stress at work for municipal police officers. Therefore, it seems justified to introduce actions aimed at strengthening the competencies of municipal police officers in helping them to deal with aggressive people.

It should be remembered that the particulars of a municipal police officer's work mainly involve the protection of public order [25-27]. As the study shows, lack of predictability can be of key importance in this context. Similar observations were made by Ogińska-Bulik [25]. In her study, she demonstrated that the mental burden of the work, as related to the unpredictability of tasks and interventions, is most stressful for employees of the public service sector (including municipal police officers).

There is no perfect method to reduce the sense of uncertainty at work, while unpredictability of the consequences of a situation can be an important stress factor. Maintaining sensible and clear thinking can help to strengthen the sense of empowerment among municipal police officers. Unfortunately, stress has a negative effect on a number of cognitive functions and on rational thinking [28]. In this context, it seems invaluable to offer training and workshops for the reference group of professionals, intended to strengthen their mental resistance to stress situations and teach them how to cope with it.

Constant availability at the workplace as a stressinducing factor was also mentioned in another study carried out in 2000, commissioned by the Polish National Police Headquarters. The study covered officers on patrol and intervention companies, police community support officers and police officers on duty. The majority of respondents mentioned the need to be available, working shifts and the lack of relevant resources as the main stressors at work [26]. These results are reflected in the present study.

Being overloaded with work, dangerous interventions, situations in which the life of a municipal police officer or citizen(s) is at risk and the sense of responsibility for the life and health of other people were of greatest significance as stress-inducing factors. No studies, however, are devoted to analysing the relationship between hazards to a municipal officer's life and stress intensity. Studies have revealed that situations which can be a hazard to the life and health of a police officer are among the most important stressful factors for uniformed services [26, 27]. OgińskaBulik [25] also emphasised direct hazard to life as a key stress-related factor at work.

In this study, it was observed that people who claimed that a municipal police officer's work was more stressful than other jobs and that they experienced stress at work, did not use any method to relieve the experienced stress more often than expected. The obtained data contradict the findings of Kozera-Wiatrowska [29], which revealed in a study of a population of 95 police officers from the Silesian region that police officers most often (ca. 90\%) chose positive thinking to relieve stress, while $60 \%$ declared doing different forms of physical activity. The discussed discrepancy can be related to the fact that the group of officers selected for the present study claimed that the job of a municipal police officer was more stressful than other jobs and that they experienced stress at work every day or often. Kozera-Wiatrowska [29] did not apply such a specific criterion in her study. 
The results of this study indicate the need to introduce relevant programmes intended to reduce the stress experienced by municipal police officers. Lack of effective methods of coping with stress can contribute not only to the deterioration of one's health but also negatively affect cognitive functions such as concentration or memory [30]. People who experience chronic and severe stress can become ill more often and evaluate their health condition as worse than people who apply effective stress-handling methods [31]. Several studies clearly indicate that chronic stress can negatively affect work effectiveness $[30,31]$.

\section{Limitations}

The applied research tool, which is a proprietary, non-standardised questionnaire, can be considered a limitation of the presented results. With regard to the characteristics of the questionnaire and the study population, the obtained results cannot be compared to any other study.

It should be pointed out that the literature offers a limited number of papers on municipal police officers, whose job specificity is different than the job specificity of police officers. In relation to the above, the majority of analysed stressors included in the nonstandardised questionnaire were based on findings for police officers. This could affect the quality of the results. Another important limitation related to the tool used was including closed questions, which could suggest answers. That is why the results should be interpreted with great care. Still, the structure of the questionnaire and the type of questions asked allow the introduction of specific preventive solutions in the municipal police structure in Warsaw, as the results of the analyses can refer to the entire population of Warsaw municipal police officers. It should be pointed out that such a numerous study population minimises the risk of errors [32], and provides an opportunity to draw reliable conclusions even if a non-standardised research tool is used.

\section{Conclusions}

Due to the specificity of a municipal police officer's occupation, special attention should be paid to the occupational stress risk factors characteristic for this group of professionals, and measures should be taken to reduce the number of stressors. It is important to organise training events devoted to effective methods of coping with stress. Finally, there is need to carry out more in-depth studies on occupational stress among municipal police officers.

\section{Conflict of interest}

None to report.

\section{References}

[1] Goldstein L, Lazarus R, Folkman S. Stress, appraisal and coping. New York: Springer-Verlag; 1984.

[2] Nakao M. Work-related stress and psychosomatic medicine. Biopsychosoc Med. 2010;4(1):4.

[3] Sęk H. Uwarunkowania i mechanizmy wypalenia zawodowego w modelu społecznej psychologii poznawczej. In: Sęk $\mathrm{H}$, editor. Wypalenie zawodowe: Przyczyny i zapobieganie. Warszawa: Wydawnictwa Naukowe PWN; 200. pp. 83-112.

[4] Główny Urząd Statystyczny [homepage on the Internet]. Wskaźniki jakości pracy. Warszawa: GUS; 2014 [access: 2018 Feb 20]; Available from: http://stat.gov.pl.

[5] Izawa S, Tsutsumi A, Ogawa N. Effort-reward imbalance, cortisol secretion, and inflammatory activity in police officers with 24-h work shifts. Int Arch Occup Environ Health. 2016;89(7):1147-1154.

[6] Ma CC, Andrew ME, Fekedulegn D, Gu JK, Hartley TA, Charles LE, et al. Shift work and occupational stress in police officers. Saf Health Work. 2015;6(1):25-29.

[7] Luceño-Moreno L, García-Albuerne Y, Talavera-Velasco B, Martín-García J. Stress in Spanish police force depending on occupational rank, sex, age and work-shift. Psicothema. 2016;28(4):389-393.

[8] Wirth MD, Andrew ME, Burchfiel CM, Burch JB, Fekedulegn D, Hartley TA, et al. Association of shiftwork and immune cells among police officers from the Buffalo Cardio-Metabolic Occupational Police Stress study. Chronobiol Int. 2017;34(6):721-731.

[9] Pancheri P, Martini A, Tarsitani L, Rosati M, Biondi M, Tomei F. Assessment of subjective stress in the municipal police force of the city of Rome. Stress Health. 2002;18(3):127-132.

[10] Setti I, Argentero P. The influence of operational and organizational stressors on the well-being of municipal police officers. Med Lav. 2013;104(5):368-379.

[11] Setti I, Argentero P. Occupational stress in municipal police officers: contribution to the Italian adaptation of a questionnaire for the assessment of the operational and organizational stressors. G Ital Med Lav Ergon. 2013;35(3):157-162.

[12] Straż Miejska m.st. Warszawy [homepage on the Internet]. Warszawa; 2018 [access: 2018 Feb 20]; Available from: http://www.strazmiejska.waw.pl/.

[13] Viotti S. Work-related stress among correctional officers: A qualitative study. Work. 2016;53(4):871-84.

[14] da Silva FC, Hernandez SSS, Arancibia BAV, da Silva Castro TL, Gutierres Filho PJB, da Silva R. Health-related quality of life and related factors of military police officers. Health Qual Life Outcomes. 2014;12(1):60.

[15] Oginska-Bulik N. The role of personal and social resources in preventing adverse health outcomes in employees of 
uniformed professions. Int J Occup Med Environ Health. 2005;18(3):233-240.

[16] Martelli TA, Waters LK, Martelli J. The police stress survey: Reliability and relation to job satisfaction and organizational commitment. Psychological Reports. 1989;64(1):267-273.

[17] Bonnar A. Stress at work: The beliefs and experiences of police superintendents. International Journal of Police Strategies and Management. 2000;2:285-302.

[18] Kop N, Euwema M. Occupational stress and the use of force by Dutch police officers. Criminal Justice and Behavior. 2001;28:631-652.

[19] Patterson GT. Examining the effects of coping and social support on work and life stress among police officers. Journal of Criminal Justice. 2003;31(3):215-226.

[20] Spielberger CD, Westberry LG, Grier KS, Greenfield G. The police stress survey: Sources of stress in law enforcement. Tampa, FL: National Institute of Justice; 1981.

[21] Violanti JM, Mnatsakanova A, Andrew ME, Hartley TA, Fekedulegn D, Baughman \&, Burchfiel CM. Associations of stress, anxiety, and resiliency in police work. Journal of Occupational and Environmental Medicine. 2014;71(Suppl 1):A3.

[22] Eye A. Configural frequency analysis. Methodology. 2007;3(4):170-172.

[23] Eye A. Configural Frequency Analysis. In Wiley StatsRef: Statistics Reference Online (eds N. Balakrishnan, T. Colton, B. Everitt, W. Piegorsch, F. Ruggeri and J. L. Teugels). 2014 doi:10.1002/9781118445112.stat06143.
[24] Opinia Komisji Bioetycznej Warszawskiego Uniwersytetu Medycznego [homepage on the Internet]. Warszawa; 2018 [access: 2018 Feb 20]; Available from: http://komisjabioetyczna.wum.edu.pl

[25] Ogińska-Bulik N. Stres zawodowy i jego konsekwencje w grupie pracowników sektora usług społecznychrola inteligencji emocjonalnej. Przegląd Psychologiczny. 2008;51(1):69-85.

[26] Hołyst B. Stres w Policji; zapobieganie jego powstawaniu i skutkom. Postępy Krminalistyki. 2000;8:5-26.

[27] Brzeźniak A, Chmielewska A, Firsiuk M, Furgała B, Kubik J. Satysfakcja z pracy policjantów i pracowników cywilnych Policji - opinie o sytuacji i warunkach pracy oraz kondycji materialnej. Szczytno: Wydział Wydawnictw i Poligrafii Wyższej Szkoły Policji w Szczytnie; 2011.

[28] Jung N, Wranke C, Hamburger K, Knauff M. How emotions affect logical reasoning: evidence from experiments with mood-manipulated participants, spider phobics, and people with exam anxiety. Front Psychol. 2014;5:570.

[29] Kozera-Wiatrowska M. Wybrane elementy stylu życia funkcjonariuszy policji z województwa śląskiego. II Kongres Młodych Ludzi Nauki - wizja, nauka, postęp; Kraków 2015.

[30] Suchecki J, Sęk H, Cieślak R. Wsparcie społeczne, stres i zdrowie. Warszawa: Wydawnictwo Naukowe PWN; 2005.

[31] Heszen I, Sęk H. Psychologia zdrowia. Warszawa: Wydawnictwo Naukowe PWN; 2007.

[32] Sedgwick P. What is sampling error? BMJ 2012;344:e4285. 